\title{
Thermo-Catalytic Reforming of spent coffee grounds
}

\author{
Mohamed Elmously ${ }^{1,3,4}$, Nils Jäger ${ }^{1}$, Andreas Apfelbacher ${ }^{1}$, Robert Daschner ${ }^{1}$ and Andreas Hornung ${ }^{1,2,3^{*}}$ (])
}

\begin{abstract}
Conversion of spent coffee grounds through the Thermo-Catalytic Reforming system $\left(T C R^{\circledR}\right)$ is evaluated in this study. While, the TCR ${ }^{\circledR}$ is a technology that has been developed by Fraunhofer UMSICHT, which combines an intermediate pyrolysis and a catalytic reforming. The temperature of the catalytic reformer is varied between 500 and $700{ }^{\circ} \mathrm{C}$ to achieve an optimum yield quantities and qualities of the products. The hydrogen concentration is maximized at a reforming temperature of $700{ }^{\circ} \mathrm{C}$, and a gas yield up to $52 \mathrm{wt} \%$ is achieved. The thermal stable bio-oil produced at $700{ }^{\circ} \mathrm{C}$ has the highest calorific value of $36.8 \mathrm{MJ} / \mathrm{kg}$ with significantly low oxygen and water content, low viscosity and Iow TAN (total acid number). Furthermore, the maximum bio-oil and char yields are obtained at the lowest reforming temperature of $500{ }^{\circ} \mathrm{C}$. Overall spent coffee grounds show a great potential as feedstock in the Thermo-Catalytic Reforming for energy and bio-chemicals production.
\end{abstract}

Keywords: Intermediate pyrolysis, $\mathrm{TCR}^{\circledR}$, Spent coffee grounds, Catalytic reforming, Sustainable fuels

\section{Introduction}

Increase in the global energy demand and the greenhouse gases crisis is one of the most important topics nowadays. The fossil based oil is an important source of energy but it is one of the reasons for an increasing carbon concentration in the atmosphere. Therefore, it is necessary to develop other renewable sources and replace the traditional fuel sources. One of these sources is the biomass, which is considered as an indirect form of solar energy. The biomass can originate from various sources, such as botanical plants, vegetation, algae, animals and organisms living on land or in water. Biomass as an initial feedstock is able to supply energy in forms of syngas, liquid bio-oil and solid fuel (Cho et al. 2016; Rao and Parulekar 1997).

Coffee is one of the highest global consumer products; the consumption of coffee beans in 2018 was estimated to be around 10.5 million tons worldwide. The coffee beans processing produce $91 \%$ of waste in the form of spent

\footnotetext{
*Correspondence: andreas.hornung@umsicht.fraunhofer.de ${ }^{1}$ Fraunhofer UMSICHT, Fraunhofer Institute for Environmental, Safety, and Energy Technology, An der Maxhütte 1, 92237 Sulzbach-Rosenberg, Germany

Full list of author information is available at the end of the article
}

coffee grounds (SCG), while the worldwide production of SCG in 2014 was predictable to be 8 million tons per year. The spent coffee grounds are the residual waste that remain after using the coffee beans through dehydration, milling and brewing. Around 50\% of SCG worldwide are produced industrially, and the remaining $50 \%$ are generated domestically (Blinová et al. 2017; Cho et al. 2017; Karmee 2018; Kelkar et al. 2015; Kim et al. 2017; Li et al. 2014; Scully et al. 2016; United States Department of Agriculture 2018).

The spent coffee grounds are regularly moved to a landfill or combusted as solid fuel. These utilization ways can cause serious pollution due to the high oxygen consumption during the decomposition of the organic components and releasing of caffeine, tannin, and polyphenols into the atmosphere (Bok et al. 2012; Kim et al. 2017). The incineration or combustion of coffee waste is also challenging, because the emissions level are not within the European standard of emissions, as it produces a higher amounts of $\mathrm{CO}$ and $\mathrm{NO}_{\mathrm{x}}$ (Galanakis 2017; Kang et al. 2017; Limousy et al. 2013). On the other hand, small parts of SCG are used as animal feed (Kelkar et al. 2015).

Furthermore, the spent coffee grounds have 2.1$3.9 \mathrm{wt} \%$ ash content, which categorizes it as 2nd and 3rd grade wood pellets. Due to the high generation of ash, the 
combustion of SCG is unstable compared to the combustion of wood pellets (Allesina et al. 2017; Kang et al. 2017).

Spent coffee grounds are valuable as biomass feedstock for bio-fuels and bio-refinery production (Li et al. 2014), due to the high organic compounds in it, such as fatty acids, lipid, cellulose, hemicellulose, lignin, carbohydrate, and nitrogen containing compounds (Cho et al. 2017; Karmee 2018). Consequently, there is a great interest in the conversion of spent coffee grounds through thermochemical processes into a syngas, bio-oil, biodiesel, or bioethanol, and char (Bok et al. 2012; Galanakis 2017; Karmee 2018; Tsai et al. 2012).

One of the treatment methods of spent coffee grounds into biogas is the anaerobic digestion. Several studies show that spent coffee grounds have a great potential for biogas production (Karmee 2018; Kim et al. 2017; Neves et al. 2006). A detailed study is carried out on anaerobic digestion of coffee residues mixed with activated sludge. The study reveals that the highest methane yield of $0.28 \mathrm{~m}^{3} \mathrm{CH}_{4}$ per $1 \mathrm{~kg}$ of initial volatile solids is reached, and it achieves $75-89 \%$ methane production efficiency (Neves et al. 2006).

Furthermore, the gasification of spent coffee grounds through a thermochemical conversion system has been investigated in a narrow scope, and reported a gas yield of $70 \%$, with a high heating value of $14.6 \mathrm{MJ} / \mathrm{m}^{3}$ (Kan et al. 2014).

Chemical composition of the spent coffee grounds makes it possible to be directly used as solid fuel for energy and heat generation (Tsai et al. 2012). Therefore, different investigations are carried out on direct combustion of SCG. It is noted that the coffee residue has a high water content of more than $55 \%$, which leads to a lower heating value of $8.4 \mathrm{MJ} / \mathrm{kg}$; thus, it should be dried to around $15 \mathrm{wt} \%$ to enhance the lower heating value up to $18.8 \mathrm{MJ} / \mathrm{kg}$. Spent coffee grounds as a solid fuel could be combusted $20 \%$ higher and longer than kiln-dried wood, and generate higher thermal power about $8.86 \mathrm{~kW}$ compared to the wood pellets with power of $8.02 \mathrm{~kW}$. However, the direct combustion generates less emission by $80 \%$ than the landfill of SCG (Allesina et al. 2017; Biobean Co. 2018; Kang et al. 2017).

In addition, several studies are carried out for a biodiesel production from the bio-oil that is extracted from the SCG. While the studies show that the produced biodiesel can offer a $10-15 \%$ reduction in $\mathrm{CO}_{2}$ emissions compared to the traditional diesel. As well a bio-hydrotreated biodiesel has successfully achieved the physicalchemical specification of commercial biodiesel (Bio-bean Co. 2018; Phimsen et al. 2016, 2017).

The pyrolysis as a thermochemical conversion technique is a promising technology and has a great potential as an alternative treatment process for biodegradable wastes. Pyrolysis provides a better conversion rate of feedstock into bio-oil, gas and solid fuel, with a high feed to bio-fuels efficiency, that could be developed worldwide as a bio-fuel and bio-chemical resource (Cho et al. 2017; Daschner et al. 2016; Hornung et al. 2011; Li et al. 2014; Tsai et al. 2012).

The conversion of spent coffee residue into valuable products through fast and slow pyrolysis has been reported in detailed in the literature. Both pyrolysis technologies have different operating parameters such as heating rates, reaction temperatures, and residence time, accordingly having different products distribution and various products' qualities (Hornung 2014).

The results from slow pyrolysis of spent coffee grounds show that increasing the heating rate or raising the pyrolysis temperature leads to a reduction in the char yield and the heating value of the char. The maximum char yield was in the range of (25-40 wt\%) (Tsai et al. 2012), the gas yield (21-24 wt\%), and the bio-oil yield (27.2-28 wt\%) (Galanakis 2017). With slow pyrolysis, the calorific value of char could reach to $31.9 \mathrm{MJ} /$ $\mathrm{kg}$; it is relatively high as compared to the char from fast pyrolysis $(29.1 \mathrm{MJ} / \mathrm{kg}$ ) (Kelkar et al. 2015; Tsai et al. 2012).

The results from fast pyrolysis of coffee grounds into bio-oil show that the yield and characteristics of the products are highly dependent on the heating rate and the reaction temperature. Furthermore, increasing the residence time in the reactor promotes the cracking of bio-oil to gas and re-polymerization to char. The produced char from the fast pyrolysis is achieved a yield in the range of (16-20.6 wt\%). Bio-oil yield is increased up to $(54.8-65 \mathrm{wt} \%)$ with raising the temperature, and then is decreased again at a higher temperature of $600{ }^{\circ} \mathrm{C}$ to 51 wt\% (Bok et al. 2012; Kelkar et al. 2015; Li et al. 2014).

The fast pyrolysis oil from SCG has high heating value HHV in range of $17.2-23 \mathrm{MJ} / \mathrm{kg}$. On the contrary, The quality of the bio-oil is relatively low, with the water content to be between 20 and $32 \mathrm{wt} \%$, nitrogen content is around $0.8-5.0 \mathrm{wt} \%$, and high oxygen content of 35-59 wt\% in the bio-oil (Bok et al. 2012; Kelkar et al. 2015; Li et al. 2014).

In addition, the non-condensable gas yield is increased to $12-20 \mathrm{wt} \%$ at the expense of both bio-oil and solid char at higher temperature that is an indication of the secondary cracking reactions of the bio-oil. It is noted that the pyrolysis gas compositions' yield is slightly increased by raising the reaction temperature, when the maximum yield of $\mathrm{CO}_{2}$ is $13.11 \mathrm{wt} \%$, CO $4.79 \mathrm{wt} \%$ and the yield of $\mathrm{H}_{2}$ is very low $<1 \mathrm{wt} \%$ (Bok et al. 2012), and $\mathrm{HHV}$ reaches up to $14.8 \mathrm{MJ} / \mathrm{kg}$ (Bok et al. 2012; Kelkar et al. 2015; Li et al. 2014). 
To enhance the qualities of pyrolysis products, and reduce the acidity, the oxygen and water content in the bio-oil, catalytic pyrolysis of spent coffee grounds is recommended, which consequently leads to improvement of the non-condensable gases (Galanakis 2017; Li et al. 2014; Yu et al. 2018).

Catalytic pyrolysis of spent coffee grounds was intensively investigated, and the results show a promotion in thermal cracking, dehydrogenation, thermal decomposition of methane and the water-gas shifting reactions due to the addition of the catalyst. While, the catalyst causes significantly increasing in the hydrogen concentration and a reduction in the $\mathrm{C}_{x} \mathrm{H}_{\mathrm{y}}$. From the mass balance point of view, the catalyst encourages the conversion and cracking of bio-oil into non-condensable gases, which leads to a reduction in bio-oil yield and increasing in non-condensable gases yield (Cho et al. 2017; Kan et al. 2014).

In general, the spent coffee grounds contain about $15 \mathrm{wt} \%$ of oil that can be extracted. Furthermore, pyrolysed bio-oil from coffee residue has a high amount of hydrophobic compounds such as fatty acids, fatty acid esters, medium-chain paraffins, olefins, and caffeine (Kelkar et al. 2015), giving it a great potential to be upgraded into biodiesel ( $\mathrm{Li}$ et al. 2014). However, spent coffee grounds bio-oil has a HHV around 20-37 MJ/kg (Cho et al. 2016; Galanakis 2017). Nevertheless, the quality of bio-oil from coffee residue is still low because of its high oxygen and water content. In another references, the bio-oil contains very high oxygen ranging from (35-59\%), water content of (20-37\%), with low HHV below 20 MJ/ kg (Bok et al. 2012; Kelkar et al. 2015; Li et al. 2014). Adding catalyst into the reaction increases the bio-oil qualities and thermally decomposes the linear hydrocarbons, furans compounds and the phenols compounds (Cho et al. 2017; Galanakis 2017).

The $\mathrm{TCR}^{\circledR}$ system as an intermediate pyrolysis combined with catalytic reforming was tested with different wastes like sewage sludge, woody biomass, agriculture residues or digestate. It is an applicable and effective technology to produce three main products (gas, bio-oil and char) with various distribution and various qualities. It was reported that increasing the catalytic reforming temperature enhances the gas yield and gas quality. Furthermore, it produces lower yield of bio-oil with high heating value, lower oxygen and water content, and low TAN number compared to other pyrolysis systems (Conti et al. 2017; Jäger et al. 2016a, b; Neumann et al. 2016a, b).

However, the applications of the biofuels from the traditional pyrolysis of SCG as an energy source are limited due to the drawback of bio-oil, such as high water and oxygen contents. In addition, the low qualities of the pyrolysis gas, low heating value and presence of tar are also derived (Galanakis 2017; Kan et al. 2014; Li et al. 2014). Moreover, the spent coffee grounds need to be dried before the fast pyrolysis up to $90-98 \%$ dry (Bok et al. 2012; Kan et al. 2014; Tsai et al. 2012).

Therefore, the aim of the present study is to investigate the possibility of the conversion of wet spent coffee grounds residue through the Thermo-Catalytic Reforming $\left(\mathrm{TCR}^{\circledR}\right)$ technology, and to characterize the product distribution and products quality obtained from different range of reforming temperatures by using a laboratory $\mathrm{TCR}^{\circledR}$ scale ( $2 \mathrm{~kg} / \mathrm{h}$ plant).

\section{Materials and methods}

\section{Thermo-Catalytic Reforming $\mathrm{TCR}^{\circledR}$ technology}

The Thermo-Catalytic Reforming $\mathrm{TCR}^{\circledR}$ system is installed at Fraunhofer UMSICHT, Institute Branch Sulzbach-Rosenberg-Germany, as shown in Fig. 1. As illustrated in Fig. 2, the $\mathrm{TCR}^{\circledR}$ lab-scale plant is a batch system, containing a screw-conveyor reactor based on intermediate pyrolysis, which is capable of processing approximately $5 \mathrm{~kg}$ of biomass, with a maximum mass flow up to $2 \mathrm{~kg} / \mathrm{h}$. The auger speed motor controls the residence time of the solid biomass to be an average of $10 \mathrm{~min}$. Three heating zones along the horizontal reactor maintain and control the temperatures between 400 and $500{ }^{\circ} \mathrm{C}$, and a heating rate of $200{ }^{\circ} \mathrm{C}-300{ }^{\circ} \mathrm{C} / \mathrm{min}$ (Ahmad et al. 2018; Conti et al. 2017; Elmously et al. 2019; Hornung et al. 2011; Hornung 2014; Jäger et al. 2016b; Neumann et al. 2016b).

The pyrolysis step is combined with an additional vertical post-reformer, while the post-reformer is the stage where the produced char acts as a catalyst at high temperatures in the range of $500{ }^{\circ} \mathrm{C}-700{ }^{\circ} \mathrm{C}$. Due to the contact of the hot char with the pyrolysed gases, the reaction between carbon dioxide and the fixed carbon in the char is stimulated and improves the water-gas shifting reactions, and enhances the secondary cracking reactions of pyrolysis products. The post-reformer is electrically heated in two heating zones, and keeps the reforming temperature in the range of $500{ }^{\circ} \mathrm{C}$ to $700{ }^{\circ} \mathrm{C}$. Leaving the post-reformer, the vapors pass through two series steps of shell and tube condensers that are controlled at $-5{ }^{\circ} \mathrm{C}$ and $0{ }^{\circ} \mathrm{C}$. The liquid phase is separated by gravity into an aqueous phase and a water phase. The non-condensable gases are driven through a washing unit, an active carbon filter, candle filter and then silica wool filter to eliminate the particles and to purify the non-condensable gases. The char is removed from the post-reformer at the end of each experiment (Ahmad et al. 2018; Conti et al. 2017; Elmously et al. 2019; Hornung et al. 2011; Hornung 2014; Jäger et al. 2016b; Neumann et al. 2016b). 


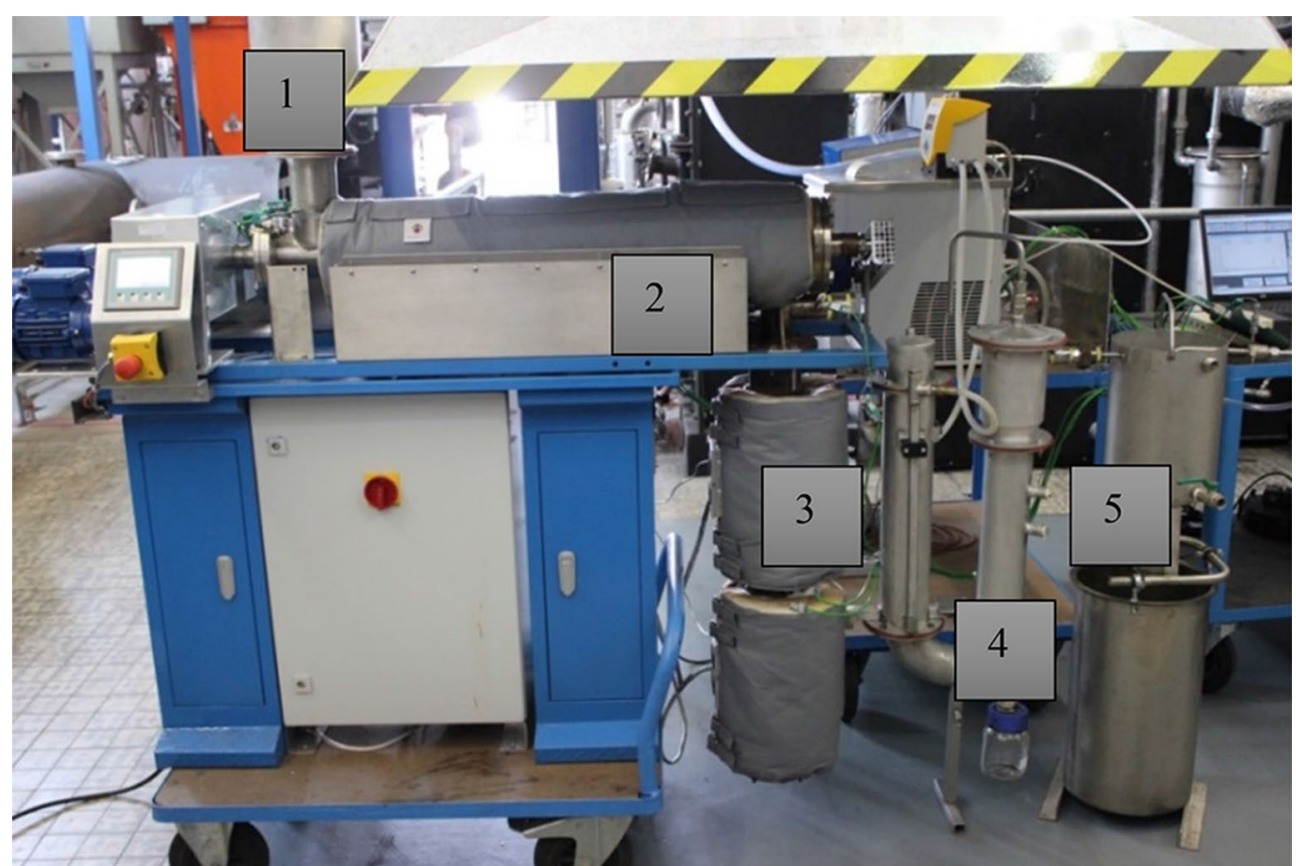

Fig. $1 \mathrm{TCR}^{\circledR} 2$ (lab scale)—maximum capacity 2 kg/h. (1) feed hopper, (2) reactor, (3) post-reformer, (4) gas cooler/condenser \#1, (5) gas cooler/ condenser \#2

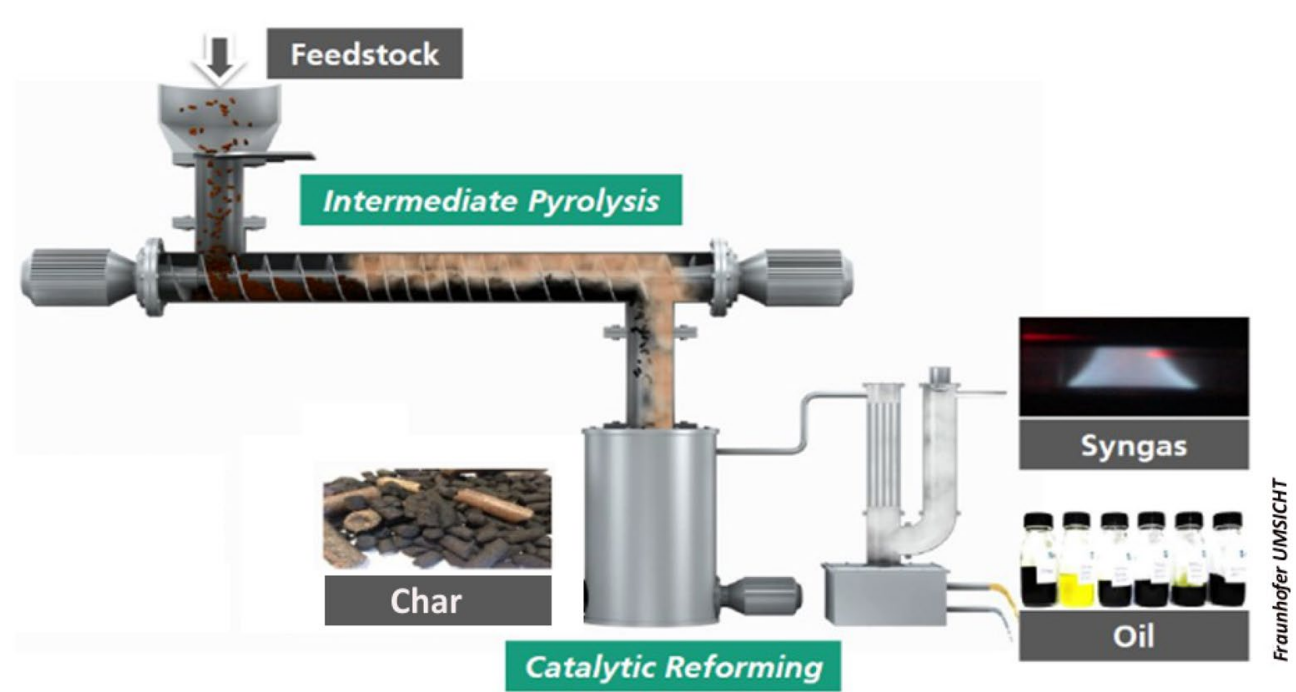

Fig. 2 Schematic principle of the $T C R^{\circledR}$ process (Jäger et al. 2016b)

Compared to other technologies, the $\mathrm{TCR}^{\circledR}$ process provides a variety of higher-quality products. It converts the wet coffee residue into storable high-quality energy carriers, produces a clean gas fraction, with high $\mathrm{H}_{2}$ and $\mathrm{CO}$ concentration, free of dust or tar, produces lower-molecular weight condensable organics, and char with high carbon content.

\section{Analytical methods and measurements}

A calibrated gas detector from Dr. Födisch Umweltmesstechnik AG (MGA 12) measures the produced gas. 
The principle of the measurement is built on an infrared photometer $\left(\mathrm{CO}, \mathrm{CO}_{2}, \mathrm{CH}_{4}\right.$, and $\left.\mathrm{C}_{\mathrm{x}} \mathrm{H}_{\mathrm{y}}\right)$, an electrochemical cell $\left(\mathrm{O}_{2}\right)$, and a thermal conductivity detector $\left(\mathrm{H}_{2}\right)$. The heating value of the gas and the density measurement are carried out with an online gas-calorimeter CWD 2005 from Union Instruments GmbH (Ahmad et al. 2018; Elmously et al. 2019; Jäger et al. 2016b). The total volume of the non-condensable gases is calculated by difference (Feed $-\left(\Sigma_{\text {char+condensate }}\right)$ (Apfelbacher et al. 2016; Elmously et al. 2019; Jäger et al. 2016b).

Elemental analysis (CHNS) of feedstock and by-products (bio-oil, char, and water phase) is carried out on a dry basis, and then the oxygen content is calculated by difference $\left(100-\left(\Sigma_{\text {CHNS+ash }}\right)\right)$. The high heating value is measured by a combustion bomb calorimeter IKA C2000 series from IKA (Elmously et al. 2019; Jäger et al. 2016b).

Total acid number (TAN) in the bio-oil is determined by 916 Oil Ti-Touch (Metrohm AG). Besides, the water content in the bio-oil is determined by Karl Fischer titration using a $915 \mathrm{KF}$ Ti-Touch titrator from Metrohm AG (Elmously et al. 2019; Jäger et al. 2016b).

The gas chromatography-mass spectrometry (GC/ MS) analysis of the bio-oil is performed on a gas chromatograph coupled with a mass spectrometer Shimadzu GC/MS-QP2020. The carrier gas is Helium with 5.0 purity, and the injection volume is set to $1 \mu \mathrm{L}$. The

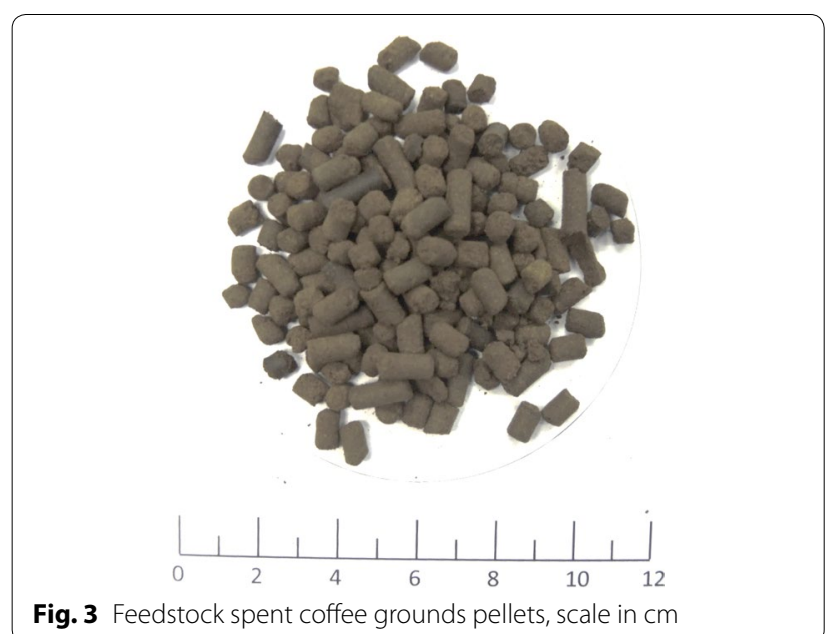

Fig. 3 Feedstock spent coffee grounds pellets, scale in cm bio-oil samples are diluted by $10 \mathrm{mg}$ of Sample in $1 \mathrm{~mL}$ of methanol $(\mathrm{MeOH})$, and with split 1:20.

\section{Raw materials}

The spent coffee ground as a raw material is a waste from the roast and ground coffee beans, which are supplied from JACOBS DOUWE EGBERTS GmbH. The spent coffee grounds are pelletized to improve its consistency, handling characteristics, increase the homogeneous of the process and reduce the dust formation. Final pellets have a diameter of $4 \mathrm{~mm}$ to $10 \mathrm{~mm}$, length $<20 \mathrm{~mm}$, and a moisture content in the range of $30-37$ wt \% with a fragile pellets structure, as shown in Fig. 3. However, $100 \%$ dry biomass is not applicable in this technology, as the water content in the feed has a big role in the reforming reactions; while at high temperature, there is a notable increase in the conversion of water (feed water + pyrolysis water) and $\mathrm{CO}$ to hydrogen. The dry basis ultimate analysis of the feedstock is reported in Table 1. It has to be noted that spent coffee grounds contain a relatively high amount of nitrogen due to a higher content of protein and caffeine. Compared to woody and agriculture biomass, the SCG residue contain low ash content $0.24 \mathrm{wt} \%$; whereas in woody biomass, it is about $2-4 \mathrm{wt} \%$. The SCG has slightly higher $\mathrm{H} / \mathrm{C}$ ratio of 0.13 compared to woody biomass of 0.12 , and lower $\mathrm{O} / \mathrm{C}$ ratio of 0.69 in SCG (woody biomass is $0.82-1.0$ ). In addition, SCG has a higher heating value of an average $22 \mathrm{MJ} / \mathrm{kg}$, compared to the woody biomass with an average of $19 \mathrm{MJ} /$ kg. (Campos-Vega et al. 2015; Jäger et al. 2016b; Kelkar et al. 2015; Tsai et al. 2012).

\section{Results and discussion}

Investigation of the spent coffee grounds as a sustainable biomass feedstock in the $\mathrm{TCR}^{\circledR}$ process is studied in terms of quality of the products, mass and energy balance. The data from the results are determined as average values from minimum of two consecutive trials at the same temperature gradient. Whereas, the pyrolysis temperature is $400{ }^{\circ} \mathrm{C}$ in the reactor and reforming temperature is varied between $500{ }^{\circ} \mathrm{C}, 600{ }^{\circ} \mathrm{C}$ and $700{ }^{\circ} \mathrm{C}$ in the post-reformer.

Table 1 Ultimate analysis of some properties on dry basis and some of physical properties of the tested SCG feedstock

\begin{tabular}{|c|c|c|c|c|c|c|c|c|c|c|}
\hline \multirow[t]{2}{*}{ Feedstock } & \multicolumn{5}{|c|}{ Ultimate analysis (wt\%) } & \multirow[t]{2}{*}{$\mathrm{H} / \mathrm{C}$ ratio } & \multirow[t]{2}{*}{$\mathrm{O} / \mathrm{C}$ ratio } & \multirow[t]{2}{*}{$\mathrm{HHV}(\mathrm{MJ} / \mathrm{kg})$} & \multicolumn{2}{|c|}{$\begin{array}{l}\text { Proximate } \\
\text { analysis (wt\%) }\end{array}$} \\
\hline & $\mathrm{C}$ & $\mathrm{H}$ & $\mathrm{N}$ & $O$ (diff.) & $S$ & & & & Ash & $\mathrm{H}_{2} \mathrm{O}$ \\
\hline SCG & 52.75 & 7.21 & 2.17 & 36.4 & 0.24 & 0.13 & 0.69 & $21.9-23.0$ & 1.24 & $30-37$ \\
\hline
\end{tabular}


Table 2 Mass balance of products from SCG through TCR $^{\circledR}$ system and other technologies

\begin{tabular}{|c|c|c|c|c|c|c|c|}
\hline System & $\begin{array}{l}\text { Heating } \\
\text { rate }\left({ }^{\circ} \mathrm{C} /\right. \\
\text { min) }\end{array}$ & Char (wt\%) & Gas (wt\%) & Condensate ${ }^{\mathbf{b}}(\mathbf{w t} \%)$ & Bio-oil (wt\%) & $\begin{array}{l}\text { Aqueous } \\
\text { phase } \\
\text { (wt\%) }\end{array}$ & References \\
\hline $\mathrm{TCR}^{\circledR}$ at $500^{\circ} \mathrm{C}$ & $200-300$ & 10.80 & 35.12 & 54.08 & 7.33 & 46.75 & \\
\hline $\mathrm{TCR}^{\circledR}$ at $600^{\circ} \mathrm{C}$ & & 8.26 & 36.87 & 54.87 & 6.22 & 48.65 & \\
\hline $\mathrm{TCR}^{\circledR}$ at $700^{\circ} \mathrm{C}$ & & 6.28 & 52.16 & 41.56 & 5.23 & 36.33 & \\
\hline Fast pyrolysis, $450^{\circ} \mathrm{C}$ to $600^{\circ} \mathrm{C}$ & 40,000 & $29-17$ & $13-20.2$ & $57.3-46$ & $-^{\mathrm{a}}$ & $--^{\mathrm{a}}$ & $\begin{array}{l}\text { Bok et al. (2012), } \\
\text { Kelkar et al. } \\
(2015)\end{array}$ \\
\hline Slow pyrolysis & 50 & 27 & 21 & 27.2 & $--^{\mathrm{a}}$ & $--^{a}$ & Galanakis (2017) \\
\hline Catalytic pyrolysis, $500^{\circ} \mathrm{C}$ to $700^{\circ} \mathrm{C}$ & 10 & $43.2-41.8$ & $0.5-22$ & $56.5-36.2$ & $--^{\mathrm{a}}$ & $--^{\mathrm{a}}$ & Cho et al. (2017) \\
\hline
\end{tabular}

a Data are not available

b Bio-oil + aqueous phase

\section{Mass balance}

The product yields from the utilization of spent coffee grounds in $\mathrm{TCR}^{\circledR}$ systems at different reforming temperatures are shown in Table 2.

In accordance with the previous studies with the TCR ${ }^{(1)}$ system, the gaseous product fraction is increasing by raising the post-reformer temperature. The amount of char and bio-oil tend to decrease. The higher temperature enhances the cracking of bio-oil and increases the water-gas shifting reactions between the gas and the char, which led to an increase in the gas yield from 32.5 to $52.2 \mathrm{wt} \%$. Consequently, the char yield is reduced from 10.8 to $6.3 \mathrm{wt} \%$. In the meantime, the bio-oil is significantly reduced from 7.3 to $5.2 \mathrm{wt} \%$. It has to be considered that the yield of condensate is separated into two phases including bio-oil and aqueous phase. In general, the aqueous phase yield, as a separated water phase from the total condensate fraction, is highly dependent on the initial moisture content of the feedstock. Therefore, the total aqueous phase amount is high in the range of 36.3$48.6 \mathrm{wt} \%$, because of the initial moisture content in the feedstock.

The mass balance distribution of products varies according to pyrolysis and reforming conditions. Moreover, the influence of temperature on the products yield in the three-pyrolysis categories (slow, intermediate, and fast) has similar trend. While it is observed in several studies that fast pyrolysis with high heating rate and significantly short residence time, produces the maximum liquid phase yield about $57.3 \mathrm{wt} \%$ and reduced to $46 \mathrm{wt} \%$ at higher temperature. On the other hand, the slow pyrolysis focuses on production of char with highest qualities and yield about $27 \mathrm{wt} \%$ at low heating rate and long residence time. The $\mathrm{TCR}^{\circledR}$ technology is based on an intermediate pyrolysis with an integrated catalytic reforming step. Therefore, it is in between the reaction conditions of slow and fast pyrolysis, whereas the products qualities are determined by the post-reformer temperature. This enables diverse product yields and qualities. Additionally, the $\mathrm{TCR}^{\circledR}$ system is distinctive by producing two separate liquid phases (organic and aqueous phase). Depending on the composition of the feedstock and the operating conditions, the product yields and composition are adjustable (Bok et al. 2012; Galanakis 2017; Hornung 2014; Kacprzak et al. 2017; Kelkar et al. 2015; Yang et al. 2014).

This is in line with Cho et al. who implemented a catalyst during the fast pyrolysis process to enhance the gas production yield from 0.5 to $22 \mathrm{wt} \%$. Additionally, it resulted in a reduction in the total condensate yield to $36.2 \mathrm{wt} \%$, due to the enhancement of the secondary cracking reactions (Cho et al. 2017).

It is obvious, that up to $52 \%$ of the product is an engine ready gaseous form, with the high quality and free of tar it could easily be used directly in engine. Although the bio-oil has low yield, it has high energy content and high quality which make it possible and economically for biofuel production.

\section{Bio-oil characterization}

The bio-oil characteristics from spent coffee grounds through $\mathrm{TCR}^{\circledR}$ system at different reforming temperatures and a comparison with fast pyrolysis are reported in Table 3. Raising the reforming temperature from 500 to $700{ }^{\circ} \mathrm{C}$ leads to an increase in the secondary cracking reaction of the bio-oil, whilst the high reforming temperature has a high positive impact on the bio-oil qualities in favor of the yield. A slight increase in the heating value is observed from 36 to $36.8 \mathrm{MJ} / \mathrm{kg}$ at temperature of $500{ }^{\circ} \mathrm{C}-700{ }^{\circ} \mathrm{C}$, respectively. $\mathrm{TCR}^{\circledR}$ oil is in the top of the range of the average heating value that reported by fast pyrolysis bio-oil of 20-37 MJ/kg (Bok et al. 2012; Cho et al. 2016; Galanakis 2017).

Moreover, it is confirmed by (Ahmad et al. 2018; Conti et al. 2017; Neumann et al. 2016a) that the presence of 


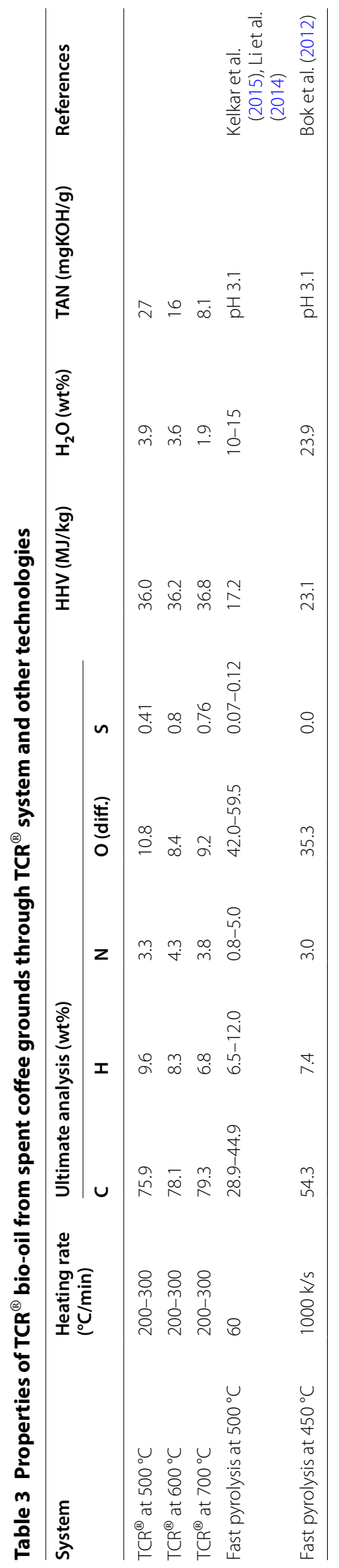


a catalytic reforming step and higher reforming temperatures have a positive impact on the reduction of the oxygen and water content and the acidity of the bio-oil. Because of the enhancement of cracking reactions and the thermal decarboxylation of organic acids in the biooil by the catalyst. The oxygen content is reduced from 10.8 to $9.2 \mathrm{wt} \%$. The TAN number is reduced from 27 to $8.1 \mathrm{mg} \cdot \mathrm{KOH} / \mathrm{g}$, by increasing the reforming temperature from 500 to $700{ }^{\circ} \mathrm{C}$, respectively.

Noticeably, the bio-oil phase is separated from the aqueous phase by gravity, due to the differences in density and polarity. With the gravitational separation, a low water content of the bio-oil of $3.9 \mathrm{wt} \%$ at $500{ }^{\circ} \mathrm{C}$ could be achieved and reduced to $1.9 \%$ at higher reforming temperature of $700{ }^{\circ} \mathrm{C}$. As mentioned earlier, the coffee residues have higher contents of nitrogen containing compounds, which leads to increase the nitrogen content in the bio-oil. In comparison to $\mathrm{TCR}^{\circledR}$-bio-oils from different feedstock, the nitrogen content is significantly higher in SGC-bio-oil of 3.3-4.8 wt\% in comparison to $2.5 \mathrm{wt} \%$ in bio-oil from woody biomass. However, a previous study at Fraunhofer UMSICHT succeeded in reducing the nitrogen content in the produced TCR ${ }^{(B)}$ bio-oil from digestate by hydrodeoxygenation (HDO), from 4.6 to $<0.1 \mathrm{wt} \%$ (Jäger et al. 2016b; Neumann et al. 2016b).
On the other hand, due to the high concentration of phenols compounds, the bio-oil has high potential for chemicals production. While, the phenols could be recovered from the bio-oil and used in the production of plastics, explosives such as picric acid, and drugs such as aspirin, and in the dye industry (Shah et al. 2017; Zhang et al. 2018).

Compared to the fast pyrolysis, the bio-oil quality is significantly lower than $\mathrm{TCR}^{\circledR}$-bio-oil. As shown in Table 3, fast pyrolysis bio-oils have a higher oxygen content of $35-59 \mathrm{wt} \%$ and water content $10-23 \mathrm{wt} \%$. Besides, the low carbon content with maximum 54.3 wt\%, with HHV up to $23.1 \mathrm{MJ} / \mathrm{kg}$. Contrary to the $\mathrm{TCR}^{\circledR}$-bio-oil, the fast pyrolysis oils have lower nitrogen and sulfur yields; this is related to the variation of the feedstock composition (Bok et al. 2012; Kelkar et al. 2015; Li et al. 2014).

The influence of the post-reformer on the improvement of the bio-oil is illustrated by the absolute intensity of the main chemical compounds obtained from the gas chromatography-mass spectrometry (GC-MS) analysis in Fig. 4 . The 25 highest concentrated components are listed in Additional file 1: Table S1, while the small peaks and unidentifiable peaks are neglected.

It is notable that raising the reforming temperature from 500 to $700{ }^{\circ} \mathrm{C}$ has a great impact on the reduction of the acids and oxygenated compounds. In addition to,

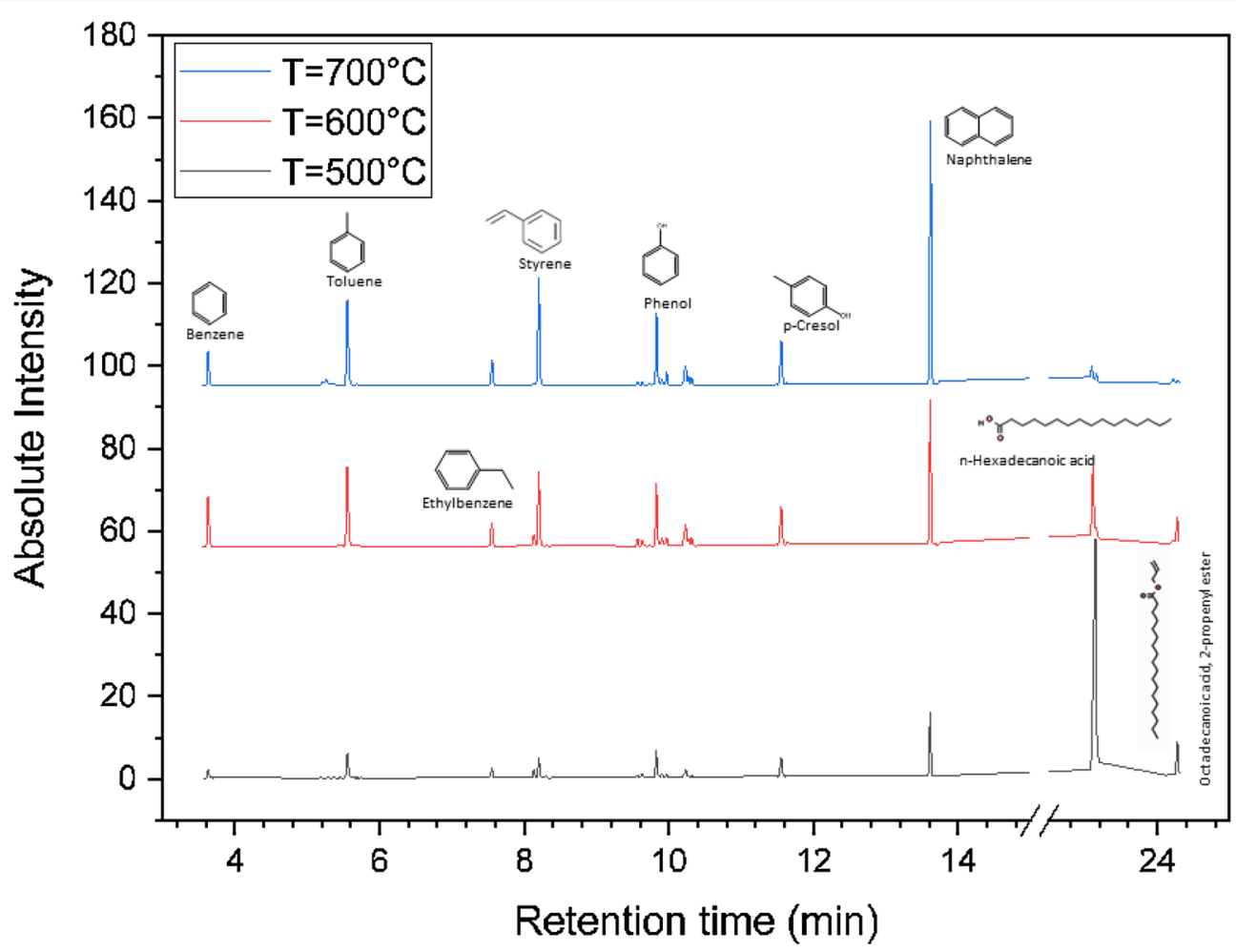

Fig. 4 GC-MS analysis of the bio-oil from SCG at reforming temperature of $500^{\circ} \mathrm{C}, 600{ }^{\circ} \mathrm{C}$ and $700{ }^{\circ} \mathrm{C}$ 
there is a remarkably cracking of the caffeine compounds in the bio-oil, due to the catalytic reforming and the secondary cracking reactions. Comparing to the fast pyrolysis where there is an apparent detection of caffeine in the bio-oil (Bok et al. 2012; Cho et al. 2016; Kelkar et al. 2015).

\section{Gas composition and characterization}

The influence of catalytic reforming temperature on the gas composition is represented in Table 5 . As shown from the results, raising the reforming temperature increases the volumetric content of hydrogen in the gas composition, and reduces the concentration of carbon dioxides. Consequently, increasing the temperature enhances the steam reforming and secondary cracking reactions.

As shown in Table 4, due to the contact of the gases with the hot $\mathrm{TCR}^{\circledR}$ char in the post-reformer, the reaction between carbon dioxide and the carbon in the hot char is stimulated, which leads to a formation of carbon monoxides. By the water-gas shifting reaction, the $\mathrm{CO}$ and water vapor can be further transformed into $\mathrm{CO}_{2}$ and $\mathrm{H}_{2}$. Furthermore, the higher reforming temperature increases the de-carbonization and decarboxylation of the oxygenated compounds in the products, which leads to the production of more $\mathrm{CO}$ and $\mathrm{CO}_{2}$.

Such reactions and equilibriums are sensitive to the temperature, while the reaction rate is increasing at higher temperature, and the conversion of reactants to

Table 4 Post-reforming reactions (Neumann et al. 2016a)

\begin{tabular}{ll}
\hline Reaction & Enthalpy (kJ/mol) \\
\hline $\mathrm{CO}_{2}+\mathrm{C} \rightleftharpoons 2 \mathrm{CO}$ & +172 \\
$\mathrm{C}+\mathrm{H}_{2} \mathrm{O} \rightleftharpoons \mathrm{CO}+\mathrm{H}_{2}$ & +131 \\
$\mathrm{CH}_{4}+\mathrm{H}_{2} \mathrm{O} \rightleftharpoons \mathrm{CO}+3 \mathrm{H}_{2}$ & +206 \\
$\mathrm{CO}+\mathrm{H}_{2} \mathrm{O} \rightleftharpoons \mathrm{CO}_{2}+\mathrm{H}_{2}$ & -41.2 \\
$\mathrm{C}+2 \mathrm{H}_{2} \rightleftharpoons \mathrm{CH}_{4}$ & -74.8 \\
\hline
\end{tabular}

products is reduced, and the tendency of reverse reaction is raised (Castro-Dominguez et al. 2016; LeValley et al. 2014; Xie et al. 2013). This explains the observed reduction of $\mathrm{CO}$ from $15.2 \mathrm{vol} \%$ at $500{ }^{\circ} \mathrm{C}$ to $11.6 \mathrm{vol} \%$ at $600{ }^{\circ} \mathrm{C}$; then it is increased again to $12.1 \mathrm{vol} \%$ at higher temperature of $700{ }^{\circ} \mathrm{C}$. On the other hand, the $\mathrm{CO}_{2}$ content kept reducing from 31.1 to $22.6 \mathrm{vol} \%$ with increasing temperatures from 500 to $700{ }^{\circ} \mathrm{C}$, respectively. These results are in line with the results reported by Neumann et al. (2016a).

The significant increase in the $\mathrm{H}_{2}$ content by $29.5 \%$ from reforming temperature $500{ }^{\circ} \mathrm{C}$ to $700{ }^{\circ} \mathrm{C}$ is as a result of water-gas shifting and the methane reforming reactions. The decomposition of methoxy and methylene groups and the cracking of the oxygenated compounds in the bio-oil produce the methane or hydrocarbon compounds in general, and reduce the density of the gas from $1.2 \mathrm{~kg} / \mathrm{m}^{3}$ at $500{ }^{\circ} \mathrm{C}$ to $0.97 \mathrm{~kg} / \mathrm{m}^{3}$ at $700{ }^{\circ} \mathrm{C}$ in combination with the increased hydrogen content. Hence, the methane reacts with steam and produces hydrogen and carbon monoxide as shown in Table 5 (Kan et al. 2014; Xie et al. 2013). The HHV is slightly decreasing with increasing reforming temperatures from 23.1 to $20.6 \mathrm{MJ} /$ $\mathrm{m}^{3}$, because of the reduction in the $\mathrm{CO}$ and $\mathrm{C}_{\mathrm{x}} \mathrm{H}_{\mathrm{y}}$ content and the increase of the hydrogen content in the gas. However, at all temperature ranges, the heating value of the $\mathrm{TCR}^{\circledR}$ gas is still higher than other technologies for syngas production from spent coffee grounds ( $\mathrm{Li}$ et al. 2014).

It is highlighted by Cho et al. 2016 that adding a catalyst during the fast pyrolysis has a great influence on thermal degradation of the bio-oil and converting it into gaseous phase. Nonetheless, the hydrogen and carbon monoxide are significantly lower than those produced by the $\mathrm{TCR}^{\circledR}$ unit (Cho et al. 2016, 2017).

Compared with anaerobic digestion of SCG for biogas production, Luz et al. 2017 studied the conversion of spent coffee grounds into gas through anaerobic

Table 5 Properties and gas composition from spent coffee grounds through TCR $^{\circledR}$ system and other technologies

\begin{tabular}{|c|c|c|c|c|c|c|c|c|c|}
\hline \multirow[t]{2}{*}{ System } & \multicolumn{5}{|c|}{ Gas composition (vol\%) } & \multirow[t]{2}{*}{ Density $\left(\mathrm{kg} / \mathrm{m}^{3}\right)$} & \multirow[t]{2}{*}{$\mathrm{HHV}\left(\mathrm{MJ} / \mathrm{m}^{3}\right)$} & \multirow[t]{2}{*}{ LHV (MJ/kg) } & \multirow[t]{2}{*}{ References } \\
\hline & $\mathrm{H}_{2}$ & $\mathrm{CO}$ & $\mathrm{CO}_{2}$ & $\mathrm{CH}_{4}$ & $\mathrm{C}_{x} \mathrm{H}_{y}$ & & & & \\
\hline $\mathrm{TCR}^{\circledR}$ at $500^{\circ} \mathrm{C}$ & 24.3 & 15.2 & 31.1 & $0.0^{b}$ & 4.9 & 1.24 & 23.1 & 17.5 & \\
\hline $\mathrm{TCR}^{\circledR}$ at $600^{\circ} \mathrm{C}$ & 34.2 & 11.6 & 24.2 & $0.04^{b}$ & 4.8 & 1.06 & 22.6 & 19.2 & \\
\hline $\mathrm{TCR}^{\circledR}$ at $700^{\circ} \mathrm{C}$ & 38.7 & 12.1 & 22.6 & $0.23^{b}$ & 3.7 & 0.97 & 20.6 & 19.1 & \\
\hline $\begin{array}{l}\text { Catalytic pyrolysis at } \\
500^{\circ} \mathrm{C} \text { to } 700{ }^{\circ} \mathrm{C}\end{array}$ & $0.5-2.2$ & $4.5-7.0$ & $--^{a}$ & $0.2-0.7$ & $-{ }^{a}$ & $-{ }^{a}$ & $-{ }^{a}$ & $-^{\mathrm{a}}$ & Cho et al. $(2016,2017)$ \\
\hline Anaerobic digestion & $-{ }^{a}$ & $-^{a}$ & $30-40$ & $50-59$ & $--^{a}$ & $-{ }^{a}$ & $-{ }^{a}$ & 28.66 & Luz et al. (2017) \\
\hline
\end{tabular}

a Data are not available

b The high content of hydrocarbons in the gases influences the detection of the other gases, especially methane caused by a crosswise relation between these compounds 
Table 6 Ultimate analysis and physical properties of the char from SCG through TCR ${ }^{\circledR}$ and other technologies

\begin{tabular}{|c|c|c|c|c|c|c|c|c|c|}
\hline \multirow[t]{2}{*}{ System } & \multicolumn{5}{|c|}{ Ultimate analysis (wt\%) } & \multirow[t]{2}{*}{$\mathrm{H} / \mathrm{C}$ ratio } & \multirow[t]{2}{*}{ HHV (MJ/kg) } & \multirow[t]{2}{*}{ Ash (wt\%) } & \multirow[t]{2}{*}{ References } \\
\hline & C & $\mathrm{H}$ & $\mathbf{N}$ & O (diff.) & $S$ & & & & \\
\hline $\mathrm{TCR}^{\circledR}$ at $500^{\circ} \mathrm{C}$ & 78.6 & 2.4 & 3.8 & 6.3 & 0.12 & 0.03 & 30.8 & 8.6 & \\
\hline $\mathrm{TCR}^{\circledR}$ at $600^{\circ} \mathrm{C}$ & 80.0 & 1.2 & 3.0 & 2.1 & 0.20 & 0.015 & 29.5 & 12.8 & \\
\hline $\mathrm{TCR}^{\circledR}$ at $700^{\circ} \mathrm{C}$ & 70.6 & 1.4 & 1.8 & 2.6 & 0.38 & 0.019 & 25.5 & 23.2 & \\
\hline Slow pyrolysis & 80.0 & 3.0 & 5.0 & 12.0 & - & 0.037 & 31.9 & 23.0 & Tsai et al. (2012) \\
\hline Fast pyrolysis at $500^{\circ} \mathrm{C}$ & 75.3 & 3.5 & 4.4 & 11.1 & 0.12 & 0.046 & $29.1^{\mathrm{a}}$ & 5.5 & Kelkar et al. (2015) \\
\hline
\end{tabular}

a Calculated value

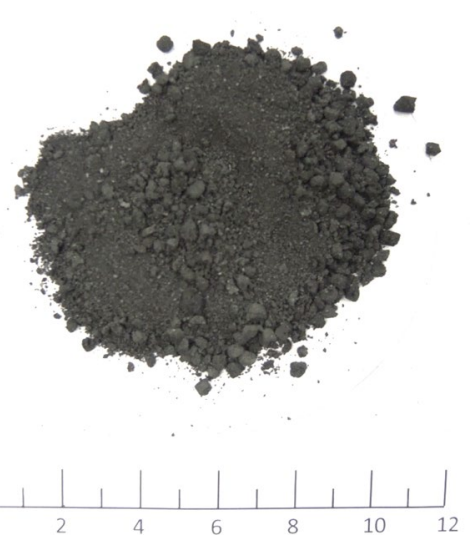

Fig. 5 The produced char from spent coffee grounds, scale in $\mathrm{cm}$

digestion with animal manure. The produced gas composition was measured as shown in Table 5. The majority of the gas is methane by maximum yield of $59 \mathrm{vol} \%$ and carbon dioxide by $40 \mathrm{vol} \%$. The low heating value LHV of $28.9 \mathrm{MJ} / \mathrm{kg}$ is higher than $\mathrm{TCR}^{\circledR}$ gas (Luz et al. 2017).

The $\mathrm{TCR}^{\circledR}$ gas balance is not closed as shown in Table 5 , due to a limitation of the gas analyser. The high content of hydrocarbons influences the detection of the other gases, especially methane caused by a crosswise relation between these compounds; the missing gas composition percentage could be nitrogen, methane or hydrogen.

\section{Char characterization}

The chemical characteristics of the $\mathrm{TCR}^{\circledR}$ char and slow pyrolysis char are presented in Table 6 . The char is produced in powder form caused by mechanical abrasion in the reactor and the thermal degradation, as shown in Fig. 5. The carbon content of the $\mathrm{TCR}^{\circledR}$ char at the two reforming temperatures $500{ }^{\circ} \mathrm{C}$ and $600{ }^{\circ} \mathrm{C}$ is similar (78.6-80 wt\%). It is reduced significantly to $70.6 \mathrm{wt} \%$ at the higher reforming temperature of $700{ }^{\circ} \mathrm{C}$. This can be explained by the increasing of the cracking reactions of the products at high temperature of $700{ }^{\circ} \mathrm{C}$.
Table 7 Energy balance of products from spent coffee grounds through TCR $^{\circledR}$ system

\begin{tabular}{llll}
\hline System & \multicolumn{3}{l}{ Energy balance (\%) } \\
\cline { 2 - 4 } & Char & Gas & Bio-oil \\
\hline $\mathrm{TCR}^{\circledR}$ at $500^{\circ} \mathrm{C}$ & 25.8 & 52.3 & 18.5 \\
$\mathrm{TCR}^{\circledR}$ at $600^{\circ} \mathrm{C}$ & 18.9 & 55.7 & 16.4 \\
$\mathrm{TCR}^{\circledR}$ at $700{ }^{\circ} \mathrm{C}$ & 11.4 & 72.8 & 14.0 \\
\hline
\end{tabular}

Raising the reforming temperature enhances the steam reforming and water-gas shifting reactions, which causes a reduction in the high heating value of the char along with the temperature from 30.8 to $15.4 \mathrm{MJ} / \mathrm{kg}$ on a dry basis. In addition, it shows a rise in the ash content with increasing the reforming temperature. Furthermore, the improvement in the heating value compared to the initial feedstock shows a potential for consumption of the char as a solid fuel. It is noticeable that the nitrogen content in the char is relatively high (3.8-1.8 wt\%); this is in line with the high initial nitrogen content in the feedstock. While, this could cause an increase in the production of nitrogen oxides $\left(\mathrm{NO}_{\mathrm{x}}\right)$ in the emissions during the char combustion (Tsai et al. 2012).

Compared to the slow and fast pyrolysis, the produced char from $\mathrm{TCR}^{\circledR}$ technology is inferior, due to the catalytic reforming reactions between the char and the condensable and non-condensable gas. The $\mathrm{TCR}^{\circledR}$ char has less oxygen content and less $\mathrm{H} / \mathrm{C}$ ratio. The low $\mathrm{H} / \mathrm{C}$ ratio gives the $\mathrm{TCR}^{\circledR}$ char the stability to be used for a carbon storage in soil (Kelkar et al. 2015; Yu et al. 2018). An alternative utilization of the char could be, for example, as an adsorbent material for filtering system (Kelkar et al. 2015).

\section{Energy balance}

Table 7 presents the energy balance of the products at different temperatures. The balance is calculated using the mass balance, water content and the LHV values of the feedstock and each product feedstock. Increasing the 
reforming temperature improves the energy content of the gaseous fraction from 52.3 to $72.8 \%$. Additionally, a reduction of the energy content of the char to $11.4 \%$ and the bio-oil to $14 \%$ at reforming temperature of $700{ }^{\circ} \mathrm{C}$ is observed. In general, about $90 \%$ of the energy content in the feedstock is transferred to the products and mainly to the gaseous phase by $70 \%$ of the total energy. However, it is noticed from the results that the products at $700{ }^{\circ} \mathrm{C}$ have high energy content about $98 \%$, due to increasing in the endothermic reactions in the post-reformer.

\section{Conclusion}

The pyrolysis of spent coffee grounds is investigated by the Thermo-Catalytic Reforming technology. The results show that the $\mathrm{TCR}^{\circledR}$ system delivers a better products distribution and better bio-fuels properties compared to typical fast pyrolysis of SCG, which creates an opportunity for bioenergy production. Because of the additional values in the products, spent coffee grounds conversion by $\mathrm{TCR}^{\circledR}$ offers a valuable utilization pathway instead of the state of the art technologies like landfilling or incineration and other conversion technologies. More combustible gases with high hydrogen content are obtained from conversion of SCGs in the TCR ${ }^{\circledR}$ system. Moreover, the obtained bio-oil has a high HHV of $36.8 \mathrm{MJ} / \mathrm{kg}$, low oxygen and low water content, and lower corrosive properties compared to the fast pyrolysis bio-oil. Likewise, the produced char with less oxygen and less $\mathrm{H} / \mathrm{C}$ ratio can be utilized in various utilization pathways such as gasification, adsorption, and soil enrichment. In the summary, the main differences between the $\mathrm{TCR}^{\circledR}$ system and the typical pyrolysis systems is the combination of the intermediate pyrolysis and post-reforming reactions, while it gives the advantages of production of higher-quality products.

\section{Supplementary information}

Supplementary information accompanies this paper at https://doi. org/10.1186/s40643-019-0281-5.

Additional file 1. A summary of gas chromatography-mass spectrometry (GC-MS) analysis of the bio-oils from TCR ${ }^{\circledR}$ system at different reforming temperature are represented in Table S1, it shows only the highest 25 concentrated components obtained from the analysis, while the small peaks and unidentifiable peaks are neglected.

\section{Abbreviations}

$\mathrm{TCR}^{\circledR}$ : Thermo-Catalytic Reforming ${ }^{\circledR}$; SCG: spent coffee grounds; $\mathrm{NiCu} / \mathrm{Y}-\mathrm{Al}_{2} \mathrm{O}_{3}$ : nickel copper/gamma-aluminum oxide; TAN: total acid number; GC-MS: gas chromatography-mass spectrometry; HDN: hydro-denitrification; HHV: high heating value; LHV: low heating value.

\section{Acknowledgements}

Mohamed Elmously would like to thank the Deutscher Akademischer Austauschdienst (DAAD) and the Egyptian cultural affairs and missions sector for financial support through Ph.D. scholarship grant (German-Egyptian
Long-Term Scholarship-GERLS-programme 2016-57222240). The authors thank the Bavarian Stat Ministry of Economic Affairs, Infrastructure, Transport and Technology for the financial support of the project. The project was conducted in the framework of the Center for Energy Storage.

\section{Authors' contributions}

ME performed the experiments and the analyzing of the products. $\mathrm{NJ}$ and $\mathrm{AA}$ contributed in analyzing the results and writing the manuscript. RD and $\mathrm{AH}$ contributed to the assessment of the results and conclusion. All authors read and approved the final manuscript.

\section{Funding}

Author "Elmously, Mohamed" his Ph.D. is funded by Deutscher Akademischer Austauschdienst (DAAD) and the Egyptian cultural affairs and missions sector for financial (German-Egyptian Long-Term Scholarship-GERLS-programme 2016-57222240).

\section{Availability of data and materials}

The datasets generated and/or analyzed during the current study are not publicly available due confidentiality of the research but are available from the corresponding author on reasonable request.

\section{Ethics approval and consent to participate}

Not applicable.

\section{Consent for publication}

Not applicable.

\section{Competing interests}

The authors declare that they have no competing interests.

\section{Author details}

${ }^{1}$ Fraunhofer UMSICHT, Fraunhofer Institute for Environmental, Safety, and Energy Technology, An der Maxhütte 1, 92237 Sulzbach-Rosenberg, Germany. ${ }^{2}$ School of Chemical Engineering, University of Birmingham, Edgbaston, Birmingham, West Midlands B15 2TT, UK. ${ }^{3}$ Friedrich-Alexander University Erlangen-Nürnberg, Schlossplatz 4, 91054 Erlangen, Germany. ${ }^{4}$ Faculty of Engineering-Mataria Branch, Helwan University, Ibrahim Abd El-Razik, Ain Shams, Cairo, Egypt.

Received: 28 August 2019 Accepted: 15 November 2019

Published online: 21 November 2019

\section{References}

Ahmad E, Jäger N, Apfelbacher A, Daschner R, Hornung A, Pant KK (2018) Integrated thermo-catalytic reforming of residual sugarcane bagasse in a laboratory scale reactor. Fuel Process Technol 171:277-286. https://doi. org/10.1016/j.fuproc.2017.11.020

Allesina G, Pedrazzi S, Allegretti F, Tartarini P (2017) Spent coffee grounds as heat source for coffee roasting plants: experimental validation and case study. Appl Therm Eng 126:730-736. https://doi.org/10.1016/j.applt hermaleng.2017.07.202

Apfelbacher A, Hornung A, Neumann J, Jäger N, Conti R, Daschner R (2016) Combined heat and power generation from solid biomass derived bioliquids and syngas by TCR. In: 24th European biomass conference and exhibition, EUBCE 2016. https://doi.org/10.5071/24theubce2016-2ao.5.5 Bio-bean Co. (2018) Coffee Logs. https://www.bio-bean.com/coffee-logs/

Blinová L, Sirotiak M, Bartošová A, Soldán M (2017) Review: utilization of waste from coffee production. Research Papers Faculty of Materials Science and Technology Slovak University of Technology 25:91-101. https://doi. org/10.1515/rput-2017-0011

Bok JP, Choi HS, Choi YS, Park HC, Kim SJ (2012) Fast pyrolysis of coffee grounds: characteristics of product yields and biocrude oil quality. Energy 47:17-24. https://doi.org/10.1016/j.energy.2012.06.003

Campos-Vega R, Loarca-Piña G, Vergara-Castañeda HA, Oomah BD (2015) Spent coffee grounds: a review on current research and future prospects. Trends Food Sci Technol 45:24-36. https://doi.org/10.1016/j. tifs.2015.04.012 
Castro-Dominguez B, Mardilovich IP, Ma L-C, Ma R, Dixon AG, Kazantzis NK, Ma YH (2016) Integration of methane steam reforming and water gas shift reaction in a $\mathrm{Pd} / \mathrm{Au} / \mathrm{Pd}$-based catalytic membrane reactor for process intensification. Membranes. https://doi.org/10.3390/membranes6030044

Cho D-W, Lee J, Yoon K, Ok YS, Kwon EE, Song H (2016) Pyrolysis of $\mathrm{FeCl}_{3}$-pretreated spent coffee grounds using $\mathrm{CO}_{2}$ as a reaction medium. Energy Convers Manag 127:437-442. https://doi.org/10.1016/j.encon man.2016.09.036

Cho DW, Kwon EE, Kwon G, Zhang S, Lee SR, Song H (2017) Co-pyrolysis of paper mill sludge and spend coffee ground using $\mathrm{CO}_{2}$ as reaction medium. J CO2 Util 21:572-579. https://doi.org/10.1016/j. jcou.2017.09.003

Conti R, Jäger N, Neumann J, Apfelbacher A, Daschner R, Hornung A (2017) Thermocatalytic reforming of biomass waste streams. Energy Technol 5:104-110. https://doi.org/10.1002/ente.201600168

Daschner R, Jäger N, Hornung A (2016) Thermo-catalytic reforming-processscale up from lab to pilot to industrial scale. Bioenergy Bioeconomy J 7:36-38

Elmously M, Jäger N, Neidel J, Apfelbacher A, Daschner R, Hornung A (2019) Upscaling of thermo-catalytic reforming process from lab to pilot scale. Ind Eng Chem Res. https://doi.org/10.1021/acs.iecr.9b00765

Galanakis CM (2017) Handbook of coffee processing by-products: sustainable applications, 1st edn. Elsevier Reference Monographs, London

Hornung A (ed) (2014) Transformation of biomass: theory to practice. Wiley, Hoboken

Hornung A, Apfelbacher A, Sagi S (2011) Intermediate pyrolysis: a sustainable biomass-to-energy concept-biothermal valorisation of biomass BtVB process. J Sci Ind Res 70:664-667

Jäger N, Conti R, Neumann J, Apfelbacher A, Daschner R, Binder S, Hornung A (2016a) Thermo-catalytic reforming (TCR ${ }^{\circledR}$ ): a platform technology to contribute present energy, environmental and resource challenges. In: Conference: 24th European biomass conference and exhibition, EUBCE 2016. https://doi.org/10.5071/24theubce2016-3ao.3.3

Jäger N, Conti R, Neumann J, Apfelbacher A, Daschner R, Binder S, Hornung A (2016b) Thermo-catalytic reforming of woody biomass. Energy Fuels 30:7923-7929. https://doi.org/10.1021/acs.energyfuels.6b00911

Kacprzak M, Neczaj E, Fijałkowski K, Grobelak A, Grosser A, Worwag M, Rorat A, Brattebo H, Almås Å, Singh BR (2017) Sewage sludge disposal strategies for sustainable development. Environ Res 156:39-46. https://doi. org/10.1016/j.envres.2017.03.010

Kan T, Strezov V, Evans T (2014) Catalytic pyrolysis of coffee grounds using NiCu-impregnated catalysts. Energy Fuels 28:228-235. https://doi. org/10.1021/ef401511u

Kang SB, Oh HY, Kim JJ, Choi KS (2017) Characteristics of spent coffee ground as a fuel and combustion test in a small boiler ( $6.5 \mathrm{~kW})$. Renew Energy 113:1208-1214. https://doi.org/10.1016/j.renene.2017.06.092

Karmee SK (2018) A spent coffee grounds based biorefinery for the production of biofuels, biopolymers, antioxidants and biocomposites. Waste Manag 72:240-254. https://doi.org/10.1016/j.wasman.2017.10.042

Kelkar S, Saffron CM, Chai L, Bovee J, Stuecken TR, Garedew M, Li Z, Kriegel RM (2015) Pyrolysis of spent coffee grounds using a screw-conveyor reactor. Fuel Process Technol 137:170-178. https://doi.org/10.1016/j.fupro c.2015.04.006

Kim J, Kim H, Baek G, Lee C (2017) Anaerobic co-digestion of spent coffee grounds with different waste feedstocks for biogas production. Waste Manag 60:322-328. https://doi.org/10.1016/j.wasman.2016.10.015

LeValley TL, Richard AR, Fan M (2014) The progress in water gas shift and steam reforming hydrogen production technologies - a review. Int J Hydrog Energy 39:16983-17000. https://doi.org/10.1016/j.ijhydene.2014.08.041

Li X, Strezov V, Kan T (2014) Energy recovery potential analysis of spent coffee grounds pyrolysis products. J Anal Appl Pyrol 110:79-87. https://doi. org/10.1016/j.jaap.2014.08.012
Limousy L, Jeguirim M, Dutournié P, Kraiem N, Lajili M, Said R (2013) Gaseous products and particulate matter emissions of biomass residential boiler fired with spent coffee grounds pellets. Fuel 107:323-329. https://doi. org/10.1016/j.fuel.2012.10.019

Luz FC, Cordiner S, Manni A, Mulone V, Rocco V (2017) Anaerobic digestion of coffee grounds soluble fraction at laboratory scale: evaluation of the biomethane potential. Appl Energy 207:166-175. https://doi. org/10.1016/j.apenergy.2017.06.042

Neumann J, Meyer J, Ouadi M, Apfelbacher A, Binder S, Hornung A (2016a) The conversion of anaerobic digestion waste into biofuels via a novel thermo-catalytic reforming process. Waste Manag 47:141-148. https:// doi.org/10.1016/j.wasman.2015.07.001

Neumann J, Jäger N, Apfelbacher A, Daschner R, Binder S, Hornung A (2016b) Upgraded biofuel from residue biomass by thermo-catalytic reforming and hydrodeoxygenation. Biomass Bioenergy 89:91-97. https://doi. org/10.1016/j.biombioe.2016.03.002

Neves L, Oliveira R, Alves MM (2006) Anaerobic co-digestion of coffee waste and sewage sludge. Waste Manag 26:176-181. https://doi.org/10.1016/j. wasman.2004.12.022

Phimsen S, Kiatkittipong W, Yamada H, Tagawa T, Kiatkittipong K, Laosiripojana $\mathrm{N}$, Assabumrungrat S (2016) Oil extracted from spent coffee grounds for bio-hydrotreated diesel production. Energy Convers Manag 126:10281036. https://doi.org/10.1016/j.enconman.2016.08.085

Phimsen S, Kiatkittipong W, Yamada H, Tagawa T, Kiatkittipong K, Laosiripojana N, Assabumrungrat S (2017) Nickel sulfide, nickel phosphide and nickel carbide catalysts for bio-hydrotreated fuel production. Energy Convers Manag 151:324-333. https://doi.org/10.1016/j.enconman.2017.08.089

Rao Sunil S, Parulekar BB (1997) Energy technology (non conventional, renewable and conventional), 2nd edn. Khanna Publishers, New Delhi

Scully DS, Jaiswal AK, Abu-Ghannam N (2016) An investigation into spent coffee waste as a renewable source of bioactive compounds and industrially important sugars. Bioengineering. https://doi.org/10.3390/bioenginee ring3040033

Shah Z, Cataluña Veses R, Ceschi MA, Silva RD (2017) Separation of phenol from bio-oil produced from pyrolysis of agricultural wastes. Mod Chem Appl. https://doi.org/10.4172/2329-6798.1000199

Tsai W-T, Liu S-C, Hsieh C-H (2012) Preparation and fuel properties of biochars from the pyrolysis of exhausted coffee residue. J Anal Appl Pyrol 93:63-67. https://doi.org/10.1016/j.jaap.2011.09.010

Xie D, Zhao J, Wang Z, Zhang Y (2013) Syngas production from oxidative methane reforming and $\mathrm{CO}$ cleaning with water gas shift reaction. Int J Hydrog Energy 38:10826-10832. https://doi.org/10.1016/j.ijhyd ene.2013.01.012

Yang Y, Brammer JG, Mahmood ASN, Hornung A (2014) Intermediate pyrolysis of biomass energy pellets for producing sustainable liquid, gaseous and solid fuels. Bioresour Technol 169:794-799. https://doi.org/10.1016/j.biort ech.2014.07.044

Yu G, Chen D, Arena U, Huang Z, Dai X (2018) Reforming sewage sludge pyrolysis volatile with Fe-embedded char: minimization of liquid product yield. Waste Manag 73:464-475. https://doi.org/10.1016/j.wasman.2017.08.004

Zhang Y, Lei H, Yang Z, Duan D, Villota E, Ruan R (2018) From glucose-based carbohydrates to phenol-rich bio-oils integrated with syngas production via catalytic pyrolysis over an activated carbon catalyst. Green Chem 20:3346-3358. https://doi.org/10.1039/C8GC00593A

\section{Publisher's Note}

Springer Nature remains neutral with regard to jurisdictional claims in published maps and institutional affiliations. 